\title{
Çalışanların Örgütsel Sinizm Düzeylerinin İncelenmesi: Konya İli Örneği (Investigation of Organizational Cinism Levels of Employees: Example of Konya Province)
}

\section{Beyza ERER iD a Mehmet ŞAHIN iD b}

a Selçuk Üniversitesi Sosyal Bilimler Meslek Yüksekokulu, Konya, Türkiye. beyzaerer@selcuk.edu.tr

b Selçuk Üniversitesi Sosyal Bilimler Meslek Yüksekokulu, Konya, Türkiye. sahinmehmet@selcuk.edu.tr

\begin{tabular}{l}
\hline MAKALE BİLGİSI \\
\hline Anahtar Kelimeler: \\
Örgütsel Sinizm \\
Bilişsel Sinizm \\
Duygusal Sinizm \\
Davranışsal Sinizm \\
Gönderilme Tarihi 25 Haziran \\
2020 \\
Revizyon Tarihi 10 Eylül 2020 \\
Kabul Tarihi 15 Eylül 2020
\end{tabular}

Makale Kategorisi:

Araştırma Makalesi

\section{ÖZET}

Amaç - Örgütsel sinizm, bireyin istihdam edildiği örgüte karşı olumsuz inanç, duygu ve davranışlar göstermesidir. Çağdaş yönetim konularında hızla yerini almaya başlayan örgütsel sinizm kavramı; örgütsel bağlllık, örgütsel performans, iş tatmini, örgütsel vatandaşlık davranışı, örgütsel gelişim ve değişim faaliyetleri gibi örgüt yararına olan faaliyetleri olumsuz etkileyerek örgütün varlığını tehdit eden bir davranış olarak ortaya çıkmaktadır. Bu bağlamda çalışmanın amacı, imalat sanayiinde çalışanların örgütsel sinizm düzeylerini belirlemek ve sosyo-demografik özellikleri ile örgütsel sinizm ve alt boyutları arasında anlamlı bir farklılığın olup olmadığını tespit etmektir.

Yöntem - Çalışma kapsamında 240 çalışana anket uygulanmış ve bulgular istatistiksel veri analizi programı kullanılarak değerlendirilmiştir. Verilerin analizinde; betimleyici analizler, bağımsız örneklemler t-testi ve ANOVA testi kullanılmıştır.

Bulgular - Analiz sonuçlarına göre katılımcıların genel örgütsel sinizm ortalamaları, bilişsel sinizm, duygusal sinizm ve davranışsal sinizm ortalamaları orta düzeydedir. Çalışanların davranışsal sinizm düzeyleri hem diğer boyutlara göre hem de örgütsel sinizmin geneline göre daha yüksektir. Çalışanların; eğitim düzeyleri, statüleri, gelir seviyeleri ve günlük çalışma süreleri ile genel örgütsel sinizm düzeyleri ve boyutları arasında anlamlı farklılıklar tespit edilmiştir. Eğitim seviyesi ve statü arttıkça sinizm düzeyinin azaldığını söylemek mümkündür.

Tartışma - Analiz sonuçlarına göre, çalışanların bazı sosyo-demografik özellikleri ile örgütsel sinizm ve alt boyutları arasında anlamlı farklılıkların olduğu saptanmıştır.

\begin{tabular}{|c|c|}
\hline ARTICLE INFO & ABSTRACT \\
\hline $\begin{array}{l}\text { Keywords: } \\
\text { Organizational Cynicism } \\
\text { Cognitive Cynicism } \\
\text { Emotional Cynicism } \\
\text { Behavioral Cynicism }\end{array}$ & $\begin{array}{l}\text { Purpose - Organizational cynicism is the negative beliefs, feelings and behaviors of employees } \\
\text { towards the organization. The concept of organizational cynicism, which has begun to take its place } \\
\text { rapidly in contemporary management issues, emerges as a behavior that threatens the existence of } \\
\text { the organization by negatively affecting activities such as organizational commitment, } \\
\text { organizational performance, job satisfaction, organizational citizenship behavior, organizational } \\
\text { development and change activities. In this context, the aim of the study is to determine the } \\
\text { organizational cynicism levels of the workers in the manufacturing industry and to determine } \\
\text { whether there is a significant difference between their socio-demographic characteristics and } \\
\text { organizational cynicism and its sub-dimensions. }\end{array}$ \\
\hline $\begin{array}{l}\text { Received } 25 \text { June } 2020 \\
\text { Revised } 10 \text { September } 2020 \\
\text { Accepted } 15 \text { September } 2020\end{array}$ & $\begin{array}{l}\text { Design/methodology/approach - Within the scope of the study, } 240 \text { employees were surveyed and } \\
\text { the findings were evaluated using statistical data analysis program. Descriptive analyzes, } \\
\text { independent samples t-test and ANOVA test were used in the analysis of the data. }\end{array}$ \\
\hline $\begin{array}{l}\text { Article Classification: } \\
\text { Research Article }\end{array}$ & $\begin{array}{l}\text { Findings - According to the results of the analysis, the average of organizational cynicism, cognitive } \\
\text { cynicism, emotional cynicism, and behavioral cynicism are at a moderate level. The behavioral } \\
\text { cynicism levels of employees are higher than both the level of other cynicism dimensions and the } \\
\text { level of general organizational cynicism. Significant differences were found between the education } \\
\text { levels, status, income levels and daily working hours of the employees and the general } \\
\text { organizational cynicism levels and dimensions. It is possible to say that as the level of education and } \\
\text { status increases, the level of cynicism decreases. }\end{array}$ \\
\hline & $\begin{array}{l}\text { Discussion-According to the results of the analysis, it has been determined that there are significant } \\
\text { differences between some socio-demographic characteristics of employees and organizational } \\
\text { cynicism and its sub-dimensions. }\end{array}$ \\
\hline
\end{tabular}

\section{Önerilen Atıf/ Suggested Citation}

Erer, B., Şahin, M. (2020). Çalışanların Örgütsel Sinizm Düzeylerinin İncelenmesi: Konya İli Örneği, İşletme Araştırmaları Dergisi, 12 (3), 2944-2959. 


\section{GİRISs}

Sinizmin temelleri M.Ö. 4. Yüzyıldaki sinik okuluna kadar dayanmaktadır. Eski Yunan'da bir düşünce tarzı ve yaşam biçimi şeklinde kaynağını bulan bu kavram, Büyük İskender'in fikirlerinden esinlenen Sinoplu Diyojen'e dayanmaktadır. Diyojen'e gündüz vakti neden fenerle dolaştığ1 sorulduğunda "dürüst bir insan arıyorum" yanıtını vermiştir. Bu yanıt, insanların gerçekte dürüst olmadığı yönündeki inancı simgeleyen sinizm kavramını ifade etmektedir (Karacaoğlu ve İnce, 2012: 78). Sinizmin örgüt ortamında gerçekleşmesi örgütsel sinizm kavramını gündeme getirmiş ve yapılan araştırmalarda örgütsel sinizmin bütün dünyada yaygın olarak görüldüğüne dikkat çekilmiştir (Kalay vd., 2014: 128).

Böylesi yaygın görülen bir kavram ile ilgili yazında farklı bilim dallarında ve farklı zamanlarda birçok araştırma yapılmıştır. Bu araştırmalarda; örgütsel sinizm kavramına ait teorik bilgiye, nedenlerine ve sonuçlarına yer verilmiş ve önerilerde bulunulmuştur. Özellikle örgütsel sinizmin nedenleri üzerine odaklanan çalışmalarda, sinizme neden olan çeşitli faktörlerin bulunduğu belirtilmektedir. Bu faktörler örgüt kaynaklı olabileceği gibi bireysel kaynaklı da olabilmektedir. Dolayısıyla kişilerin sahip olduğu sosyodemografik özellikler birey kaynaklı faktörler kapsamında yer almaktadır. Bunlar; cinsiyet, medeni durum, yaş, eğitim düzeyi, statü, sahip olunan çocuk sayısı, hizmet süresi, çalışma saati ve gelir gibi özelliklerden oluşmaktadır. Söz konusu özellikler örgütsel sinizm çalışmalarında kontrol ya da aracı değişken olarak kullanılmış ve benzer ya da farklı sonuçlara ulaşılmıştır (Anderson ve Bateman, 1997; James, 2005; Efilti vd., 2008; Tokgöz ve Yılmaz, 2008; Tınaztepe, 2012; Yılmaz vd., 2016; Çankaya, 2018). Ancak her bilim dalı kendi perspektifinden konuya yaklaşarak bilimsel hayata ve iş hayatına katkı sağlayacak sonuçlara ulaşmıştır. Dolayısıyla, örgütü olumsuz etkileyen bu tarz kavramların farklı bilim dallarında, farklı sektörlerde ve farklı dönemlerde yapılmasının faydalı olacağı düşüncesiyle yapılan bu araştırmanın önem taşıdığı düşünülmektedir. Bu kapsamda çalışmanın amacı, imalat sanayi çalışanlarının örgütsel sinizm düzeylerini belirleyerek, sosyo-demografik özellikleri ile örgütsel sinizm düzeyleri arasında anlamlı bir farklılığın olup olmadığını ortaya koymaktır. Bu doğrultuda, çalışmada ilk olarak örgütsel sinizme ilişkin teorik bilgiye yer verilmiş ve daha sonra uygulama bölümüne geçilmiştir.

\section{2.ÖRGÜTSEL SINIIZM}

Sinizm olgusu her ne kadar son yıllarda yaygın kullanılmaya başlamış olsa da kökeni M.Ö. IV. y.y.'a kadar uzanan bir Antik Yunan felsefesi ya da hayat tarzı olarak karşımıza çıkmaktadır (Akdemir vd., 2016: 116). Kişilerin sadece kendi menfaatlerini koruduğuna inanan ve bu duruma bağlı olarak herkesi menfaatçi olarak gören kimse "sinik" ve bu kavramı ifade etmeye yardımcı olan düşünce ise "sinizm" olarak tanımlanmaktadır (Yalçın, 2017: 4). Sinizme ait esas inanç; adalet, dürüstlük ve içtenlik gibi unsurların bireysel menfaatler uğruna feda edilmesi yönündedir. Dolayısıyla sinizm, "güvensizlik, hor görme, iğrenme, umutsuzluk, hayal kırıklığı, hüsran" sözcükleriyle nitelendirilen bir tutumdur (James, 2005: 1).

Sinizm, bireysel olduğu gibi örgütsel kökenli de olabilmektedir (Kalağan ve Güzeller, 2010: 84). Çünkü sinizm ile ilgili olan tutum ve davranışların çok sık bir biçimde her çeşit örgütte görülmesi sonucunda örgütsel sinizm kavramı gündeme gelmiş ve alan yazında örgütsel sinizm ile alakalı birçok tanım yapılmıştır. Bu tanımlar arasında en yaygın kullanılanlardan biri Dean ve arkadaşlarının (1998); atfetme, beklenti, sosyal değişim, tutum, duygusal olaylar ve sosyal güdülenme kuramlarını dikkate alarak kavramsallaştırdığı tanımıdır. Söz konusu tanıma göre, kişinin bulunduğu örgüte karşı geliştirdiği olumsuz davranışlar "örgütsel sinizm" olarak ifade edilmekte ve bilişsel-duygusal-davranışsal olmak üzere üç alt boyutta ele alınmaktadır (Dean vd., 1998: 345).

İlk alt boyut olan bilişsel sinizm; kızgınlık ve hor görme gibi olumsuz duygular sonucunda ortaya çıkmakta ve örgütün doğruluktan mahrum olduğu inancını vurgulamaktadır. Bu nedenle örgütsel sinizm; iyi ve içten olmayan davranışlar ve güdüler ile alakalı inançsızlık eğilimidir. Dolayısıyla sinikler, örgütlerindeki uygulamalarda doğruluk, dürüstlük ve adalet gibi ilkelerin olmadığına inanmaktadırlar (Dean vd., 1998: 345). Duygusal sinizm, herhangi bir obje karşısında gösterilen duygusal reaksiyonlardır. Çalışanların bilişsel boyuttaki algılamaları ardından duygusal boyut kapsamındaki kızgınlık, sıkıntı ve utanma gibi güçlü tepkiler şeklinde kendini gösterir (Abraham, 2000: 269). Davranışsal sinizm ise, negatif ve çoğunlukla küçümseyici davranışta bulunma eğilimine sahiptir. Örgütüne karşı sinik tutumları olan çalışanların en belirgin davranışsal eğilimi örgütüne ilişkin yapmış olduğu sert eleştirilerdir. Bu boyut ayrıca karamsar tahminleri, manidar bakışları ve alaycı mizah gibi davranışları da kapsamaktadır (Brandes, 1997: 34-35; Dean vd., 1998: 
346). Sonuç olarak örgütsel sinizm; inanç, duygu ve davranışlardan oluşan çok boyutlu bir kavramdır. Örgüt çalışanı bilişsel aşamada örgütün dürüstlükten yoksun olduğunu düşünerek duygusal aşamada örgüte karşı öfke, sıkıntı ve utanma gibi bazı olumsuz duygularla tepkisini ortaya koymakta ve davranışsal aşamada da harekete geçerek olumsuz davranışlar sergilemektedir.

Örgütsel yazın incelendiğinde, bireysel ve örgütsel birçok faktörün örgütsel sinizmi etkilediği görülmektedir. Bu faktörlerden; cinsiyet, medeni durum, yaş, eğitim düzeyi, statü, sahip olunan çocuk sayısı, hizmet süresi, çalışma saati ve gelir bireysel faktörler (Cartwright, Holmes, 2006) olarak ele alınırken psikolojik sözleşme ihlalleri, iletişimsizlik, kişi-rol çatışması, örgütsel adaletsizlik algısı ve yüksek yönetici maaşları ise örgütsel faktörler olarak ele alınmıştır (Anderson ve Bateman, 1997). Bu örgütsel faktörler haricinde diğer örgütsel faktörleri de aşağıdaki gibi sıralamak mümkündür (Pelit ve Pelit, 2014: 93);

- Doğru yönetilmeyen değişim uğraşları, küçülme ve yeniden yapılanma çabaları,

- Yoğun stres, aşırı iş yükü ve prosedürlerden kaynaklanan adaletsizlik,

- Terfi düzeylerinin yeterli olmaması,

- Çalışma saatlerinin uzun olması,

- Yıldırma ve dengeli olmayan güç dağılımı,

- Sosyal desteklerin yeterli olmaması,

- Kişisel beklentilerin karşılanmaması,

- Kişisel ve örgütsel amaçların uyumlaştırılmaması,

- Örgütsel karmaşıklığın ve politikaların artış göstermesi,

- İş değerlerinin geleneksel biçimlerde sürdürülmesi,

- Ani şekilde gerçekleştirilen işten çıkarmalar,

- Etkili olmayan karar mekanizmaları.

Tüm bu nedenlere bağlı olarak ortaya çıkan örgütsel sinizm hem çalışanlar hem de örgütler açısından çok çeşitli ve olumsuz sonuçlara yol açmaktadır. Bu doğrultuda, örgütsel sinizmin sonuçları bireysel ve örgütsel olarak ikiye ayrılır.

1)Bireysel Sonuçlar: Bireysel yönden psikolojik, fizyolojik ve davranışsal sonuçları vardır. Yapılan araştırmalarda, örgütsel sinizmin sinirsel ve duygusal bozukluklara yol açtığı; depresyon, uykusuzluk ve hayal kırıklığı gibi rahatsızlıklara sebep olduğu belirtilmiştir (Mirvis ve Kanter, 1991). Bireyleri ruhsal ve sosyolojik olarak güçlü bir şekilde etkisi altına alan sinizm sinirlenme, gerilim, kaygılanma ve hırçınlaşma gibi psikolojik sonuçlara neden olmaktadır (Gençer, 2017: 33). Kişinin fizyolojisini de etkileyen sinizm kalp ve damar hastalıkları gibi rahatsızlıklara sebebiyet vermekte ve bu da bireyin yaşam süresini olumsuz etkilemektedir (Karadeniz, 2017: 88). Ayrıca sinik çalışanlar yönetime karşı çıkmakta veya örgütü aşağılama eğilimine girerek aşırı derecede vandalizm, misilleme veya sabotaj davranışlarında bulunabilmektedirler (Mishna ve Spreitzer, 1998: 571).

2)Örgütsel Sonuçlar: Örgütsel açıdan sinizm, örgütsel etkinliği ve verimliliği azaltırken ciddi anlamda hem maddi hem de manevi kayıplara yol açarak önemli sonuçlar ortaya çıkmaktadır. Bunlar; çalışanların örgüte karşı olan bağlılıkların azalması ya da yok olması, örgütsel vatandaşlık davranışlarının azalması veya yok olması, işe karşı hissedilen doyumsuzluk, iş gücü devir oranında artışların yaşanması, işten çıkarılma ve ayrılma oranlarında yaşanan artış, sabotaj, hırsızlık ve dolandırıcılığın artması, örgüt yapılarında ortaya çıkan küçülmeler, örgüt kurallarına uyum sağlanmaması, itaatsizlik, örgüte karşı kuşku duyma ve güvensizlikte artış, işe yabancılaşma, örgütsel performansın düşmesi, duygusal tükenmede meydana gelen artış, etik kurallara uymama, olumsuz tutum ve davranışlarda artış, motivasyon kaybı, örgütü aşağılamada yaşanan artış, örgüt liderlerine karşı güvenin azalması, örgütsel gelişim ve değişim için gösterilen çabada isteksizlik ve çalışanlar arasında iletişimde zayıflık gibi çok geniş bir alana yayılan sonuçlardır (Anderson ve Bateman, 1997: 463; Mantere ve Martinsuo, 2001: 78-79; Rubin vd., 2009, 680; Kalağan, 2009: 81-82; Kutanis ve Çetinel, 2010: 189).

Örgütlerde giderek yaygın hale gelen sinizm bahsi geçen birçok olumsuz sonuçlara yol açmaktadır. Örgütsel sinizmi yönetmek, azaltmak hatta ortadan kaldırmak için örgütünde sinik davranışları gören yöneticiler örgütsel sinizme neden olan faktörleri araştırarak söz konusu sinik davranışları ortadan kaldırmaya çalışmalıdır. Bunun için yöneticiler (Reichers vd., 1997: 53; Özgener vd., 2008; Efilti vd., 2008: 281); 
- Çalışanlar ile yönetim arasında güven ve iş birliği duygusunu geliştirmeli,

- Adil bir yönetim yapısı oluşturmalı,

- Örgütteki çalışma şartlarını iyileştirmeli,

- Örgütsel esneklik oluşturmalı ve bu durumu yaygınlaştırmalı,

- Örgüt içinde oluşan monotonluğu azaltmalı,

- İlişki odaklı davranışı vurgulamalı,

- Sinik tutumları değiştirmek için çalışanlara danışmanlık yapmalı,

- Çalışanları kendilerini ilgilendiren karar mekanizmasına dâhil etmeli,

- Çalışanlarda ortaya çıkabilecek stresi azaltarak tükenmişliğin önüne geçmeli,

- Zamanı verimli kullanmayı sağlamalı,

- Çalışanlar arasında oluşabilecek rekabeti etkili yönetmeli,

- Çalışanların beklentilerini karşılamalı,

- Çalışanları her anlamda (maddi, manevi, sosyal ve kültürel) desteklemeli,

- Çalışanlara yeni fırsatlar sunmalı,

- Çalışanları daha iyi anlamak için çift yönlü iletişimi kullanmalı,

- Beğenilen, güvenilen ve rasyonel sözcükleri ve olumlu mesajları kullanmalı,

- Hataları kabul edip, gerektiğinde özür dilemeli ve gerekli düzenlemeleri yapmalı,

- Empatik yaklaşımlar sergilemeli,

- Zamanlamanın etkinliğini arttırmalı,

- Ani değişimleri en aza indirgemeli ve yapılan değişimler için çalışanları bilgilendirilmelidir.

\section{YÖNTEM}

\subsection{Araştırmanın Amacı ve Hipotezleri}

Araştırmanın amacl; imalat sanayiinde çalışanların örgütsel sinizm düzeylerini belirlemek ve sosyodemografik özellikleri ile örgütsel sinizm ve alt boyutları arasında anlamlı farklılık olup olmadığını tespit etmektir. Araştırmanın amacı doğrultusunda geliştirilen hipotezler aşağıdaki gibidir:

H1: Cinsiyet değişkeni ile örgütsel sinizm arasında anlamlı bir farklılık vardır.

H1a: Cinsiyet değişkeni ile bilişsel sinizm arasında anlamlı bir farklılık vardır.

H1b: Cinsiyet değişkeni ile duygusal sinizm arasında anlamlı bir farklılık vardır.

H1c: Cinsiyet değişkeni ile davranışsal sinizm arasında anlamlı bir farklılık vardır.

H2: Medeni durum değişkeni ile örgütsel sinizm arasında anlamlı bir farklılık vardır.

H2a: Medeni durum değişkeni ile bilişsel sinizm arasında anlamlı bir farklılık vardır.

H2b: Medeni durum değişkeni ile duygusal sinizm arasında anlamlı bir farklılık vardır.

H2c: Medeni durum değişkeni ile davranışsal sinizm arasında anlamlı bir farklılık vardır.

H3: Yaş gurubu değişkeni ile örgütsel sinizm arasında anlamlı bir farklılık vardır.

H3a: Yaş grubu değişkeni ile bilişsel sinizm arasında anlamlı bir farklılık vardır.

H3b: Yaş grubu değişkeni ile duygusal sinizm arasında anlamlı bir farklılık vardır.

H3c: Yaş grubu değişkeni ile davranışsal sinizm arasında anlamlı bir farklılık vardır.

H4: Eğitim düzeyi değişkeni ile örgütsel sinizm arasında anlamlı bir farklılık vardır.

H4a: Eğitim düzeyi değişkeni ile bilişsel sinizm arasında anlamlı bir farklılık vardır.

H4b: Eğitim düzeyi değişkeni ile duygusal sinizm arasında anlamlı bir farklılık vardır.

H4c: Eğitim düzeyi değişkeni ile davranışsal sinizm arasında anlamlı bir farklılık vardır.

H5: Sahip olunan çocuk sayısı değişkeni ile örgütsel sinizm arasında anlamlı bir farklılık vardır.

H5a: Sahip olunan çocuk sayısı değişkeni ile bilişsel sinizm arasında anlamlı bir farklılık vardır.

H5b: Sahip olunan çocuk sayısı değişkeni ile duygusal sinizm arasında anlamlı bir farklılık vardır. 


\section{B. Erer - M. Şahin 12/3 (2020) 2944-2959}

H5c: Sahip olunan çocuk sayısı değişkeni ile davranışsal sinizm arasında anlamlı bir farklılık vardır.

H6: Statü değişkeni ile örgütsel sinizm arasında anlamlı bir farklılık vardır.

H6a: Statü değişkeni ile bilişsel sinizm arasında anlamlı bir farklılık vardır.

H6b: Statü değişkeni ile duygusal sinizm arasında anlamlı bir farklılık vardır.

H6c: Statü değişkeni ile davranışsal sinizm arasında anlamlı bir farklılık vardır.

H7: İş tecrübesi değişkeni ile örgütsel sinizm arasında anlamlı bir farklılık vardır.

H7a: İş tecrübesi değişkeni ile bilişsel sinizm arasında anlamlı bir farklılık vardır.

H7b: İş tecrübesi değişkeni ile duygusal sinizm arasında anlamlı bir farklılık vardır.

H7c: İş tecrübesi değişkeni ile davranışsal sinizm arasında anlamlı bir farklılık vardır.

H8: Mevcut işletmedeki çalışma yılı değişkeni ile örgütsel sinizm arasında anlamlı bir farklılık vardır.

H8a: Mevcut işletmedeki çalışma yılı değişkeni ile bilişsel sinizm arasında anlamlı bir farklılık vardır.

H8b: Mevcut işletmedeki çalışma yılı değişkeni ile duygusal sinizm arasında anlamlı bir farklılık vardır.

H8c: Mevcut işletmedeki çalışma yılı değişkeni ile davranışsal sinizm arasında anlamlı bir farklılık vardir.

H9: Aylık gelir değişkeni ile örgütsel sinizm arasında anlamlı bir farklılık vardır.

H9a: Aylık gelir değişkeni ile bilişsel sinizm arasında anlamlı bir farklılık vardır.

H9b: Aylık gelir değişkeni ile duygusal sinizm arasında anlamlı bir farklılık vardır.

H9c: Aylık gelir değişkeni ile davranışsal sinizm arasında anlamlı bir farklılık vardır.

H10: Günlük çalışma saati değişkeni ile örgütsel sinizm arasında anlamlı bir farklılık vardır.

H10a: Günlük çalışma saati değişkeni ile bilişsel sinizm arasında anlamlı bir farklılık vardır.

H10b: Günlük çalışma saati değişkeni ile duygusal sinizm arasında anlamlı bir farklılık vardır.

H10c: Günlük çalışma saati değişkeni ile davranışsal sinizm arasında anlamlı bir farklılık vardır.

\subsection{Araştırmanın Evreni ve Örneklemi}

Araştırma için uygulamanın yapıldığı tarihlerde Konya il merkezinde faaliyette bulunan ana metal sanayi çalışanları evren olarak belirlenmiştir. Bu bağlamda araştırma örneklemi, Konya Sanayi Odası'na kayıtlı ana metal sanayinde faaliyet gösteren ve en az 10 yıllık geçmişi olan 34 farklı işletmede çalışan toplam 240 çalışandan oluşmaktadır. Kolayda örnekleme yönteminin kullanıldığı araştırmamızda maksimum çeşitlilik sağlanmaya çalışılmıştır. Kolayda örnekleme, evren içinden seçilecek örnek kesiminin araştırmayı yapan kişinin yargılarınca saptandığı örnekleme yöntemidir (Çankaya, 2020: 270). Evren büyüklüğüne ait sağlıklı bir veri setine ulaşılmadığından bazı araştırmacılar, örneklem büyüklügünün evreni temsil etmesi için 100'den fazla olması gerektiğini savunmaktadırlar (Akgemci vd., 2020: 69). Buna göre örneklem büyüklügünün araştırmayı adil bir biçimde temsil ettiğini söylemek mümkündür.

\subsection{Veri Toplama Aracı ve Verilerin Analizinde Kullanılan Teknikler}

Nicel araştırma yönteminin kullanıldığı bu çalışmada, veri toplama aracı olarak anket tekniği kullanılmıştır. Anket formu internet tabanlı hazırlanmış ve katılımclara iletilmiştir. Kullanılan anket formunun birinci bölümünde, katılımcıların sosyo-demografik özelliklerine (cinsiyet, medeni durum, yaş gurubu, eğitim düzeyi, sahip olunan çocuk sayısı, statü, iş tecrübesi, mevcut işletmedeki toplam çalışma yılı, aylık gelir seviyesi ve günlük çalışma saati) ilişkin sorular yer almaktadır.

Anket formunun ikinci bölümde, katılımcıların örgütsel sinizm davranışlarını belirlemek amacıyla Brandes vd. (1999) tarafından geliştirilen, Kalağan (2009) tarafından akademisyenler üzerinde Türkçeye uyarlanan ve Karacaoğlu ve Aslan (2012) tarafından ise imalat sanayi çalışanları üzerinde geçerlilik ve güvenirliği yapılmış 
olan "Örgütsel Sinizm Ölçeği” kullanılmıştır. Ölçek 13 ifadeden ve 3 alt boyuttan (bilişsel, duygusal ve davranışsal) oluşmaktadır. Bu ifadelerden; ilk beşi bilişsel, bunları izleyen dördü duygusal ve son dördü ise davranışsal boyut ile ilgilidir. Örgütsel sinizme ait ifadeler 5'li likert ölçeğine göre düzenlenmiş ve ölçeğin toplam puan aralığı 13-65 arasında değişmektedir. Ayrıca ölçekte ters madde bulunmamakta olup ölçekten alınan yüksek puanlar örgütsel sinizm düzeylerinin yüksek olduğunu göstermektedir.

Araştırmada kullanılan ölçek ile ilgili diğer bilgiler Tablo 1'de verilmektedir.

Tablo 1. Ölçeğin Cronbach's Alpha Katsayıları ile Madde Sayıları

\begin{tabular}{llll}
\hline & Karacaoğlu ve Aslan (2012) & Bu araştırmada & \\
\hline & Cronbach's $\boldsymbol{\alpha}$ & Cronbach's $\boldsymbol{\alpha}$ & Madde Sayısı \\
\hline $\begin{array}{l}\text { Örgütsel Sinizm } \\
\text { Ölçeği }\end{array}$ & 0,94 & 0,96 & 13 \\
\hline Bilişsel Sinizm & 0,87 & & 5 \\
\hline Duygusal Sinizm & 0,82 & 0,94 & 4 \\
\hline Davranışsal Sinizm & 0,70 & 0,94 & 4 \\
\hline
\end{tabular}

Tablo 1'e göre örgütsel sinizm ölçeği ve boyutlarının güvenilirliğinin yeterli seviyede olduğunu söylemek mümkündür $(\alpha>0,70)$.

Araştırma sonucunda elde edilen veriler, SPSS Statistics 20.0 kullanılarak değerlendirilmiştir. Verilerin değerlendirilmesinde parametrik veya parametrik olmayan testlere karar vermeden önce normallik denemesi yapılmıştır. Ölçeğin toplam puan ve alt boyutları ile ilgili yapılan normal dağılım testi sonucunda hem $p>0,05$ çıkmış hem de skewness (çarpıklık) ve kurtosis (basıklık) katsayılarının -2 ile +2 arasında değerler aldığı sonucuna ulaşılmıştır. İstatistiksel analizlerde skewness ve kurtosis katsayı değerlerinin ideal olarak +1 ve -1 arasında olmasının arzulandığı, fakat katsayı değerlerinin -2 ile +2 değer aralığında olmasının da normal dağılım için kabul edilebilir olduğu ifade edilmektedir (Yalçın ve Koyuncu, 2014: 90). Bu nedenle çalışanların sosyo-demografik özellikleri ile örgütsel sinizm davranışları arasında anlamlı farklılık olup olmadığını belirlemek için parametrik testlerin kullanılmasına karar verilmiş ve verilerin analizinde; Frekans ve Yüzde Analizi, Bağımsız Örneklemler T-Testi ve ANOVA Testi (varyanslar homojen ise Tukey, değil ise Games-Howell testi) kullanılmıştır.

\subsection{Sinırlılıklar}

Araştırma konu ve uygulama açısından bazı kısıtlar taşımaktadır. Araştırmanın konusu, imalat sanayi çalışanlarının örgütsel sinizm düzeylerini sadece sosyo-demografik özellikler yönünden incelenmesi ile kısıtlıdır. Araştırma maliyet ve zaman yönünden değerlendirildiğinde, verileri toplama işlemi 28.04.2020 10.06.2020 tarihleri arasında gerçekleştirilmiştir. Ayrıca sonuçlar, araştırma kapsamında yer alan hipotezler ile sınırlı olduğundan dolayı sonuçların genellenmesi gibi bir amaç bulunmamaktadır.

\section{BULGULAR}

Araştırmanın bu bölümünde, araştırmaya katılan çalışanların sosyo-demografik özellikleri ile ilgili frekans ve yüzde analizi sonuçlarına, örgütsel sinizm ve örgütsel sinizm alt boyutlarına vermiş oldukları cevapların en düşük-en yüksek ortalama ve standart sapma değerlerine ve hipotez test sonuçlarına yer verilmiştir. Bu doğrultuda öncelikle araştırmaya katılan çalışanların demografik özellikleri tablo halinde sunulmuş, daha sonra katılanların örgütsel sinizm ve boyutlarına ilişkin cevapları verilmiş en sonda ise araştırma hipotezlerine ait testler ve bu testlere ait tablolar sunulmuştur. 


\subsection{Demografik Bulgular}

Araştırma kapsamındaki işletmelerde ankete katılan 240 kişiye ilişkin sosyo-demografik özellikler Tablo 2'de gösterilmektedir.

Tablo 2. Katılımcıların Sosyo-Demografik Özelliklerine İlişkin Tanımlayıcı İstatistikler

\begin{tabular}{|c|c|c|c|c|c|c|c|}
\hline \multicolumn{2}{|l|}{ Parametreler } & \multirow{2}{*}{$\begin{array}{l}\mathbf{f} \\
48 \\
\end{array}$} & \multirow{2}{*}{$\begin{array}{l}\% \\
20 \\
\end{array}$} & \multicolumn{2}{|l|}{ Parametreler } & \multirow{2}{*}{$\begin{array}{l}\mathbf{f} \\
61 \\
\end{array}$} & \multirow{2}{*}{$\begin{array}{l}\% \\
25,4 \\
\end{array}$} \\
\hline Cinsiyet & Kadın & & & \multirow{4}{*}{ Çocuk Sayısı } & Yok & & \\
\hline & Erkek & 192 & 80 & & 1 & 51 & 21,3 \\
\hline \multirow[t]{2}{*}{ Medeni Durum } & Evli & 170 & 70,8 & & 2 & 66 & 27,5 \\
\hline & Bekâr & 70 & 29,2 & & 3 ve üstü & 62 & 25,9 \\
\hline \multirow{5}{*}{ Yaş Grubu } & $18-25$ & 25 & 10,4 & \multirow[t]{2}{*}{ Statü } & Yönetici & 51 & 21,3 \\
\hline & $26-30$ & 49 & 20,4 & & İşçi & 189 & 77,5 \\
\hline & $31-35$ & 63 & 26,3 & \multirow{5}{*}{$\begin{array}{l}\text { Meslekteki } \\
\text { Çalışma Yılı }\end{array}$} & $1-5$ yil & 54 & 22,5 \\
\hline & $36-40$ & 57 & 23,8 & & 6-10 yıl & 54 & 22,5 \\
\hline & 41 ve üstü & 46 & 19,2 & & $11-15$ yıl & 58 & 24,2 \\
\hline \multirow{4}{*}{ Eğitim Düzeyi } & İlköğretim & 63 & 26,3 & & $16-20 \mathrm{yll}$ & 47 & 19,6 \\
\hline & Lise & 75 & 31,3 & & 21 yıl ve üzeri & 27 & 11,3 \\
\hline & Ön Lisans & 37 & 15,4 & \multirow{5}{*}{$\begin{array}{l}\text { İşletmedeki } \\
\text { Çalışma Yılı }\end{array}$} & $1-5$ yil & 131 & 54,6 \\
\hline & Lisans & 65 & 27,1 & & 6-10 y1l & 69 & 28,8 \\
\hline \multirow{5}{*}{ Aylık Gelir } & 1500-2000TL & 13 & 5,4 & & $11-15$ yil & 24 & 10 \\
\hline & 2001-3000TL & 76 & 31,7 & & $16-20$ yil & 12 & 5 \\
\hline & 3001-4000TL & 51 & 21,3 & & 21 yıl ve üzeri & 4 & 1,7 \\
\hline & 4001-5000TL & 45 & 18,8 & \multirow{2}{*}{$\begin{array}{l}\text { Günlük } \\
\text { Çalışma Saati }\end{array}$} & 8 saat ve alt1 & 72 & 30 \\
\hline & 5001 ve üstü & 55 & 22,9 & & 9 saat ve üstü & 168 & 70 \\
\hline
\end{tabular}

\subsection{Katılımcıların Örgütsel Sinizm ve Boyutlarına Vermiş Oldukları Cevapların İncelenmesi}

Araştırmaya katılan çalışanların örgütsel sinizm ve örgütsel sinizm alt boyutlarına vermiş oldukları cevapların en düşük-en yüksek değerler, ortalama ve standart sapma değerlerine ilişkin sonuçlar Tablo 3'te gösterilmektedir.

Tablo 3. Katılımcıların Örgütsel Sinizm ve Boyutlarına Vermiş Oldukları Cevapların İncelenmesi

\begin{tabular}{|l|l|l|l|}
\hline Örgütsel Sinizm ve Boyutları & Min-Max & Ortalama & Standart Sapma \\
\hline Örgütsel Sinizm (Genel) & $1-5$ & 3,16 & 0,99 \\
\hline Bilişsel Sinizm & $1-5$ & 3,22 & 1,74 \\
\hline Duygusal Sinizm & $1-5$ & 2,82 & 1,15 \\
\hline Davranışsal Sinizm & $1-5$ & 3,46 & 1,02 \\
\hline
\end{tabular}

Katılımcların örgütsel sinizme ait ifadelere verdikleri yanıtlar sonucunda ortaya çkan ortalamanın yorumlanmasında Çankaya (2018)'in çalışmasında esas aldığı kesit değerler kullanılmıştır. Bu değerlere göre ortalamaları; 1,0-2,33 arasındaki değerler düşük katılım, 2,34-3,66 arasındaki değerler orta düzeyde katılım ve 3,67-5,00 arasındaki değerler ise yüksek katılımı temsil etmektedir. Bu kapsamda Tablo 3 incelendiğinde katılımcıların örgütsel sinizm ve tüm boyutlarına 1-5 değerleri arasında katılım gösterdikleri görülmektedir. Ayrıca; örgütsel sinizm genelinde ve tüm boyutlarda ortalama değer 2,34-3,66 aralığında olduğu için çalışanların sinizm düzeyleri orta düzeydedir.

\subsection{Hipotez Testleri}

Araştırmaya katılan çalışanların cinsiyet, medeni durum, statü ve günlük çalışma saati değişkenlerine göre örgütsel sinizm ölçeği ve alt boyutlarının toplam puanları arasında herhangi bir anlamlı farklılığın olup olmadığını belirlemek için T-testi yapılmıştır. Diğer demografik değişkenler olan yaş, eğitim düzeyi, sahip olunan çocuk sayısı, iş tecrübesi, mevcut işletmedeki çalışma yılı ve gelir değişkenleri ile örgütsel sinizm ölçeği ve alt boyutlarının toplam puanları arasında anlamlı farklılı̆̆ın olup olmadığını belirlemek için ise ANOVA testi yapılmıştır. Yapılan analiz sonuçları aşağıda tablolar halinde gösterilmiştir. 
B. Erer - M. Şahin 12/3 (2020) 2944-2959

Tablo 4. Cinsiyet Değişkeni İçin T-Testi Sonuçları

\begin{tabular}{|c|c|c|c|c|c|c|}
\hline & Cinsiyet & $\mathbf{n}$ & Ort & SS & $\mathbf{t}$ & $\mathrm{p}$ \\
\hline \multirow[t]{2}{*}{ Toplam Puan } & Kadın & 48 & 39,47 & 12,38 & \multirow[t]{2}{*}{0,964} & \multirow[t]{2}{*}{0,331} \\
\hline & Erkek & 192 & 41,48 & 13,04 & & \\
\hline \multirow[t]{2}{*}{ Bilişsel Sinizm } & Kadın & 48 & 15,00 & 5,27 & \multirow[t]{2}{*}{1,641} & \multirow[t]{2}{*}{0,106} \\
\hline & Erkek & 192 & 16,41 & 5,36 & & \\
\hline \multirow[t]{2}{*}{ Duygusal Sinizm } & Kadın & 48 & 11,02 & 4,41 & \multirow[t]{2}{*}{0,464} & \multirow[t]{2}{*}{0,643} \\
\hline & Erkek & 192 & 11,36 & 4,63 & & \\
\hline \multirow[t]{2}{*}{ Davranışsal Sinizm } & Kadın & 48 & 13,45 & 3,74 & \multirow[t]{2}{*}{0,371} & \multirow[t]{2}{*}{0,711} \\
\hline & Erkek & 192 & 13,70 & 4,17 & & \\
\hline
\end{tabular}

$\mathrm{p}>0,05$

Katılımcıların cinsiyetleri ile örgütsel sinizm ( $t=0,964 ; p>0,05)$, bilişsel sinizm alt boyutu $(t=1,641 ; p>0,05)$, duygusal sinizm alt boyutu $(t=0,464 ; p>0,05)$ ve davranışsal sinizm alt boyutu $(t=0,371 ; p>0,05)$ toplam puanları arasında anlamlı bir farklılığın olmadığ tespit edilmiştir. H1, H1a, H1b, H1c hipotezleri reddedilmiştir.

Tablo 5. Medeni Durum Değişkeni İçin T-Testi Sonuçları

\begin{tabular}{|c|c|c|c|c|c|c|}
\hline & $\begin{array}{l}\text { Medeni } \\
\text { Durum }\end{array}$ & n & Ort & SS & $t$ & $p$ \\
\hline \multirow{2}{*}{ Toplam Puan } & Evli & 170 & 41,42 & 12,49 & \multirow[t]{2}{*}{0,641} & \multirow[t]{2}{*}{0,521} \\
\hline & Bekâr & 70 & 40,25 & 13,93 & & \\
\hline \multirow[t]{2}{*}{ Bilişsel Sinizm } & Evli & 170 & 16,20 & 5,20 & \multirow{2}{*}{0,333} & \multirow{2}{*}{0,754} \\
\hline & Bekâr & 70 & 15,95 & 5,77 & & \\
\hline \multirow[t]{2}{*}{ Duygusal Sinizm } & Evli & 170 & 11,33 & 4,52 & \multirow[t]{2}{*}{0,211} & \multirow[t]{2}{*}{0,842} \\
\hline & Bekâr & 70 & 11,20 & 4,75 & & \\
\hline \multirow[t]{2}{*}{ Davranışsal Sinizm } & Evli & 170 & 13,88 & 3,88 & \multirow[t]{2}{*}{1,284} & \multirow[t]{2}{*}{0,213} \\
\hline & Bekâr & 70 & 13,10 & 4,52 & & \\
\hline
\end{tabular}

$\mathrm{p}>0,05$

Katılımcların medeni durumları ile örgütsel sinizm ( $t=0,641 ; p>0,05)$, bilişsel sinizm alt boyutu ( $t=0,333$; $\mathrm{p}>0,05)$, duygusal sinizm alt boyutu $(t=0,211 ; p>0,05)$ ve davranışsal sinizm alt boyutu $(t=1,284 ; p>0,05)$ toplam puanları arasında anlamlı bir farklılığın olmadığı tespit edilmiştir. $\mathbf{H}_{2}, \mathbf{H}_{2 a}, \mathbf{H}_{2 b}, \mathbf{H}_{2 c}$ hipotezleri reddedilmiştir.

Tablo 6. Yaş Değişkeni İçin ANOVA Testi Sonuçları

\begin{tabular}{|c|c|c|c|c|c|c|c|}
\hline & Yaş & $\mathbf{n}$ & Ort & SS & $\mathbf{F}$ & $p$ & Farklılık \\
\hline \multirow{5}{*}{ Toplam Puan } & a) $18-25$ & 25 & 43,84 & 15,22 & \multirow{5}{*}{0,752} & \multirow{5}{*}{0,585} & \multirow{5}{*}{ - } \\
\hline & b) $26-30$ & 49 & 40,66 & 13,87 & & & \\
\hline & c) $31-35$ & 63 & 40,25 & 12,42 & & & \\
\hline & d) $36-40$ & 57 & 42,70 & 12,08 & & & \\
\hline & e)41 ve üstü & 46 & 39,19 & 12,26 & & & \\
\hline \multirow{5}{*}{ Bilişsel Sinizm } & a) $18-25$ & 25 & 17,88 & 6,08 & \multirow{5}{*}{0,895} & \multirow{5}{*}{0,485} & \multirow{5}{*}{ - } \\
\hline & b) $26-30$ & 49 & 15,96 & 5,66 & & & \\
\hline & c)31-35 & 63 & 15,56 & 5,46 & & & \\
\hline & d) $36-40$ & 57 & 15,56 & 5,08 & & & \\
\hline & e)41 ve üstü & 46 & 15,63 & 4,82 & & & \\
\hline \multirow{5}{*}{$\begin{array}{l}\text { Duygusal } \\
\text { Sinizm }\end{array}$} & a) $18-25$ & 25 & 12,04 & 5,17 & \multirow{5}{*}{0,696} & \multirow{5}{*}{0,627} & \multirow{5}{*}{ - } \\
\hline & b) $26-30$ & 49 & 11,10 & 4,70 & & & \\
\hline & c) $31-35$ & 63 & 10,92 & 4,58 & & & \\
\hline & d) $36-40$ & 57 & 11,93 & 4,52 & & & \\
\hline & e)41 ve üstü & 46 & 10,83 & 4,29 & & & \\
\hline \multirow{5}{*}{$\begin{array}{l}\text { Davranışsal } \\
\text { Sinizm }\end{array}$} & a) $18-25$ & 25 & 13,92 & 4,73 & \multirow{5}{*}{0,741} & \multirow{5}{*}{0,593} & \multirow{5}{*}{ - } \\
\hline & b) $26-30$ & 49 & 13,59 & 4,65 & & & \\
\hline & c) $31-35$ & 63 & 13,78 & 3,36 & & & \\
\hline & d) $36-40$ & 57 & 14,21 & 4,02 & & & \\
\hline & e) 41 ve üstü & 46 & 12,74 & 4,08 & & & \\
\hline
\end{tabular}

$\mathrm{p}>0,05$ 
Katılımcıların yaş grubu ile örgütsel sinizm $(0,752 ; \mathrm{p}>0,05)$, bilişsel sinizm alt boyutu $(\mathrm{F}=0,895 ; \mathrm{p}>0,05)$, duygusal sinizm alt boyutu $(\mathrm{F}=0,696 ; \mathrm{p}>0,05)$ ve davranışsal sinizm alt boyutu $(\mathrm{F}=0,741 ; \mathrm{p}>0,05)$ toplam puanları arasında anlamlı bir farklılık tespit edilmemiştir. $\mathbf{H}_{3}, \mathbf{H}_{3 a}, \mathbf{H}_{3 \mathbf{b}}, \mathbf{H}_{3 c}$ hipotezleri reddedilmiştir.

Tablo 7. Eğitim Düzeyi Değişkeni İçin ANOVA Testi Sonuçları

\begin{tabular}{|c|c|c|c|c|c|c|c|}
\hline & Eğitim Durumu & $n$ & Ort & SS & $F$ & $p$ & Farklılık \\
\hline \multirow{4}{*}{ Toplam Puan } & a)İlköğretim & 63 & 45,23 & 13,54 & \multirow{4}{*}{5,967} & \multirow{4}{*}{$0,000^{* *}$} & \multirow{4}{*}{$\begin{array}{l}a>c \\
a>d \\
b>c \\
b>d\end{array}$} \\
\hline & b)Lise & 75 & 43,71 & 11,65 & & & \\
\hline & c)Ön lisans & 37 & 36,00 & 13,00 & & & \\
\hline & d)Lisans & 65 & 36,94 & 11,65 & & & \\
\hline \multirow{4}{*}{$\begin{array}{l}\text { Bilişsel } \\
\text { Sinizm }\end{array}$} & a)İlköğretim & 63 & 17,76 & 5,35 & \multirow{4}{*}{6,866} & \multirow{4}{*}{$0,000^{* *}$} & \multirow{4}{*}{$\begin{array}{l}a>c \\
a>d \\
b>c \\
b>d\end{array}$} \\
\hline & b)Lise & 75 & 17,49 & 5,02 & & & \\
\hline & c)Ön lisans & 37 & 14,41 & 5,34 & & & \\
\hline & d)Lisans & 65 & 13,97 & 4,85 & & & \\
\hline \multirow{4}{*}{$\begin{array}{l}\text { Duygusal } \\
\text { Sinizm }\end{array}$} & a)İlköğretim & 63 & 12,60 & 4,80 & \multirow{4}{*}{3,394} & \multirow{4}{*}{$0,010^{*}$} & \multirow{4}{*}{$\begin{array}{l}a>c \\
a>d\end{array}$} \\
\hline & b)Lise & 75 & 11,81 & 4,19 & & & \\
\hline & c)Ön lisans & 37 & 9,97 & 4,22 & & & \\
\hline & d)Lisans & 65 & 10,18 & 4,66 & & & \\
\hline \multirow{4}{*}{$\begin{array}{l}\text { Davranışsal } \\
\text { Sinizm }\end{array}$} & a)İlköğretim & 63 & 14,87 & 4,33 & \multirow{4}{*}{5,439} & \multirow{4}{*}{$0,000^{* *}$} & \multirow{4}{*}{$\begin{array}{l}a>c \\
a>d \\
b>c\end{array}$} \\
\hline & b)Lise & 75 & 14,40 & 3,56 & & & \\
\hline & c)Ön lisans & 37 & 11,62 & 4,44 & & & \\
\hline & d)Lisans & 65 & 12,78 & 3,62 & & & \\
\hline
\end{tabular}

${ }^{*} \mathrm{p}<0,05 ;{ }^{* *} \mathrm{p}<0,01$

Katılımcıların eğitim düzeyleri ile örgütsel sinizm ( $\mathrm{F}=5,967 ; \mathrm{p}<0,01)$, bilişsel sinizm alt boyutu $(\mathrm{F}=6,866 ; \mathrm{p}<0,01)$, duygusal sinizm alt boyutu $(\mathrm{F}=3,394 ; \mathrm{p}<0,05)$ ve davranıssal sinizm alt boyutu $(\mathrm{F}=5,439 ; \mathrm{p}<0,01)$ toplam puanları arasında anlamlı farklılıkların bulunduğu tespit edilmiştir. H4, H4a, H4b, H4c hipotezleri kabul edilmiştir. Farkın hangi gruplar arasında olduğunu belirlemek için örgütsel sinizm ölçeği ve alt boyutları toplam puanlarının varyanslarına bakılmış ve varyanslar homojen olduğu için Tukey testi yapılmıştır. Bu doğrultuda, araştırma örneklem kapsamındaki ilköğretim mezunu çalışanların örgütsel sinizm, bilişsel sinizm, duygusal sinizm ve davranışsal sinizm toplam puanlarının ön lisans ve lisans mezunu çalışanlardan anlamlı bir şekilde yüksek olduğu tespit edilmiştir. Ayrıca lise mezunu çalışanların örgütsel sinizm, bilişsel sizim ve davranışsal sinizm toplam puanlarının ön lisans ve lisans mezunu olanlara göre daha yüksek olduğu tespit edilmiştir.

Tablo 8. Sahip Olunan Çocuk Sayısı Değişkeni İçin ANOVA Testi Sonuçları

\begin{tabular}{|c|c|c|c|c|c|c|c|}
\hline & Çocuk Sayısı & $\mathbf{n}$ & Ort & SS & $\mathbf{F}$ & p & Farklılık \\
\hline \multirow{4}{*}{ Toplam Puan } & a)Yok & 61 & 39,30 & 14,36 & \multirow{4}{*}{2,118} & \multirow{4}{*}{0,099} & \multirow{4}{*}{-} \\
\hline & b) 1 & 51 & 38,67 & 13,35 & & & \\
\hline & c) 2 & 66 & 41,94 & 11,32 & & & \\
\hline & d)3 ve üstü & 62 & 43,94 & 12,29 & & & \\
\hline \multirow{4}{*}{$\begin{array}{l}\text { Bilişsel } \\
\text { Sinizm }\end{array}$} & a)Yok & 61 & 15,59 & 5,80 & \multirow{4}{*}{1,923} & \multirow{4}{*}{0,127} & \multirow{4}{*}{ - } \\
\hline & b) 1 & 51 & 15,14 & 4,53 & & & \\
\hline & c) 2 & 66 & 16,24 & 5,04 & & & \\
\hline & d)3 ve üstü & 62 & 17,37 & 4,85 & & & \\
\hline \multirow{4}{*}{$\begin{array}{l}\text { Duygusal } \\
\text { Sinizm }\end{array}$} & a)Yok & 61 & 10,79 & 4,05 & \multirow{4}{*}{1,137} & \multirow{4}{*}{0,335} & \multirow{4}{*}{ - } \\
\hline & b) 1 & 51 & 10,67 & 4,82 & & & \\
\hline & c) 2 & 66 & 11,61 & 4,28 & & & \\
\hline & d)3 ve üstü & 62 & 11,98 & 4,32 & & & \\
\hline \multirow{4}{*}{$\begin{array}{l}\text { Davranışsal } \\
\text { Sinizm }\end{array}$} & a)Yok & 61 & 12,92 & 4,67 & \multirow{4}{*}{2,666} & \multirow{4}{*}{0,071} & \multirow{4}{*}{ - } \\
\hline & b) 1 & 51 & 12,86 & 4,21 & & & \\
\hline & c) 2 & 66 & 14,10 & 3,08 & & & \\
\hline & d)3 ve üstü & 62 & 14,58 & 4,14 & & & \\
\hline
\end{tabular}

$\mathrm{p}>0,05$ 
B. Erer - M. Şahin 12/3 (2020) 2944-2959

Katılımcıların sahip oldukları çocuk sayısı ile örgütsel sinizm ( $F=2,118 ; p>0,05)$, bilişsel sinizm alt boyutu $(\mathrm{F}=1,923 ; \mathrm{p}>0,05)$, duygusal sinizm alt boyutu $(\mathrm{F}=1,137 ; \mathrm{p}>0,05)$ ve davranışsal sinizm alt boyutu ( $\mathrm{F}=2,666$; $\mathrm{p}>0,05)$ toplam puanları arasında anlamlı bir farklılık tespit edilmemiştir. H5, H5a, H5b, H5c hipotezleri reddedilmiştir.

Tablo 9. Statü Değişkeni İçin T-Testi Sonuçları

\begin{tabular}{|c|c|c|c|c|c|c|}
\hline & Statü & $\mathbf{n}$ & Ort & SS & $t$ & p \\
\hline \multirow{2}{*}{ Toplam Puan } & a)Yönetici & 51 & 36,37 & 11,67 & \multirow[b]{2}{*}{$-2,986$} & \multirow[b]{2}{*}{$0,003^{*}$} \\
\hline & b) İşçi & 189 & 42,36 & 12,97 & & \\
\hline \multirow[t]{2}{*}{ Bilişsel Sinizm } & a)Yönetici & 51 & 13,65 & 4,82 & \multirow[b]{2}{*}{$-3,832$} & \multirow[b]{2}{*}{$0,000^{* *}$} \\
\hline & b) İşçi & 189 & 16,80 & 5,32 & & \\
\hline \multirow{2}{*}{$\begin{array}{l}\text { Duygusal } \\
\text { Sinizm }\end{array}$} & a)Yönetici & 51 & 9,86 & 4,62 & \multirow[b]{2}{*}{$-2,542$} & \multirow[b]{2}{*}{$0,012^{*}$} \\
\hline & b)İşçi & 189 & 11,68 & 4,51 & & \\
\hline \multirow{2}{*}{$\begin{array}{l}\text { Davranışsal } \\
\text { Sinizm }\end{array}$} & a)Yönetici & 51 & 12,86 & 3,58 & \multirow[b]{2}{*}{$-1,572$} & \multirow[b]{2}{*}{0,117} \\
\hline & b)İşçi & 189 & 13,87 & 4,20 & & \\
\hline
\end{tabular}

$\mathrm{p}>0,05,{ }^{*} \mathrm{p}<0,05,{ }^{* *} \mathrm{p}<0,01$

Katılımcların statüleri ile örgütsel sinizm $(t=-2,986 ; p<0,05)$, bilişsel sinizm alt boyutu $(t=-3,832 ; p<0,01)$ ve duygusal sinizm alt boyutu $(\mathrm{t}=-2,542 ; \mathrm{p}<0,05)$ toplam puanları arasında anlamlı farklılıkların bulunduğu tespit edilmiştir. Davranışsal sinizm alt boyutunun $(t=-1,572 ; p>0,05)$ toplam puanının ise statü değişkeninden etkilenmediği sonucuna ulaşılmıştır H6, H6a ve H6b hipotezleri kabul edilirken, H6c hipotezi ise reddedilmiştir. Araştırma örneklemi kapsamında işçilerin örgütsel sinizm, bilişsel sinizm alt boyutu ve duygusal sinizm alt boyutu toplam puanları yöneticilere göre yüksektir.

Tablo 10. İş Tecrübesi Değişkeni İçin ANOVA Testi Sonuçları

\begin{tabular}{|c|c|c|c|c|c|c|c|}
\hline & İş Tecrübesi & $\mathbf{n}$ & Ort & SS & $\mathbf{F}$ & p & Farklılık \\
\hline \multirow{5}{*}{ Toplam Puan } & a)1-5 yll & 54 & 41,24 & 13,67 & \multirow{5}{*}{0,422} & \multirow{5}{*}{0,792} & \multirow{5}{*}{ - } \\
\hline & b)6-10 y1l & 54 & 41,52 & 14,00 & & & \\
\hline & c)11-15 yıl & 58 & 41,36 & 12,29 & & & \\
\hline & d)16-20 yıl & 47 & 39,09 & 11,61 & & & \\
\hline & e)21 yıl ve üstü & 27 & 42,81 & 13,12 & & & \\
\hline \multirow{5}{*}{$\begin{array}{l}\text { Bilişsel } \\
\text { Sinizm }\end{array}$} & a)1-5 yıl & 54 & 16,06 & 5,55 & \multirow{5}{*}{0,465} & \multirow{5}{*}{0,761} & \multirow{5}{*}{ - } \\
\hline & b)6-10 y1l & 54 & 16,17 & 5,87 & & & \\
\hline & c)11-15 y1l & 58 & 15,86 & 5,24 & & & \\
\hline & d)16-20 yıl & 47 & 15,79 & 5,07 & & & \\
\hline & e)21 yıl ve üstü & 27 & 17,41 & 4,92 & & & \\
\hline \multirow{5}{*}{$\begin{array}{l}\text { Duygusal } \\
\text { Sinizm }\end{array}$} & a)1-5 yll & 54 & 11,74 & 4,79 & \multirow{5}{*}{0,759} & \multirow{5}{*}{0,553} & \multirow{5}{*}{ - } \\
\hline & b) $6-10$ y1l & 54 & 11,17 & 5,06 & & & \\
\hline & c) $11-15$ yıl & 58 & 11,38 & 4,68 & & & \\
\hline & d)1-20 y1l & 47 & 10,41 & 3,47 & & & \\
\hline & e)21 yıl ve üstü & 27 & 12,04 & 4,79 & & & \\
\hline \multirow{5}{*}{$\begin{array}{l}\text { Davranışsal } \\
\text { Sinizm }\end{array}$} & a)1-5 yıl & 54 & 13,44 & 4,59 & \multirow{5}{*}{0,891} & \multirow{5}{*}{0,470} & \multirow{5}{*}{ - } \\
\hline & b)6-10 yıl & 54 & 14,19 & 4,15 & & & \\
\hline & c)11-15 yıl & 58 & 14,12 & 3,28 & & & \\
\hline & d)16-20 yıl & 47 & 12,89 & 4,22 & & & \\
\hline & e)21 y1l ve üstü & 27 & 13,37 & 4,25 & & & \\
\hline
\end{tabular}

$\mathrm{p}>0,05$ 


\section{B. Erer - M. Şahin 12/3 (2020) 2944-2959}

Katılımcıların iş tecrübeleri ile örgütsel sinizm ( $F=0,422 ; p>0,05)$, bilişsel sinizm alt boyutu $(F=0,465 ; p>0,05)$, duygusal sinizm alt boyutu $(\mathrm{F}=0,759 ; \mathrm{p}>0,05)$ ve davranışsal sinizm alt boyutu $(\mathrm{F}=0,891 ; \mathrm{p}>0,05)$ toplam puanları arasında anlamlı bir farklılık tespit edilmemiştir. $\mathbf{H 7 , ~} \mathbf{H 7 a}, \mathbf{H 7 b}, \mathbf{H 7 c}$ hipotezleri reddedilmiştir.

Tablo 11. Mevcut İşletmedeki Çalışma Yılı Değişkeni İçin ANOVA Testi Sonuçları

\begin{tabular}{|c|c|c|c|c|c|c|c|}
\hline & $\begin{array}{l}\text { Mevcut } \\
\text { İşletmedeki } \\
\text { Çalışma Yılı }\end{array}$ & $\mathbf{n}$ & Ort & sS & $\mathbf{F}$ & p & Farklılık \\
\hline \multirow{5}{*}{ Toplam Puan } & a) $1-5$ yll & 131 & 42,33 & 13,54 & \multirow{5}{*}{2,111} & \multirow{5}{*}{0,080} & \multirow{5}{*}{ - } \\
\hline & b)6-10 yil & 69 & 41,69 & 10,84 & & & \\
\hline & c) $11-15 \mathrm{yll}$ & 24 & 37,21 & 10,95 & & & \\
\hline & d)16-20 yıl & 12 & 33,83 & 16,53 & & & \\
\hline & e) 21 yıl ve üstü & 4 & 34,75 & 17,50 & & & \\
\hline \multirow{5}{*}{ Bilişsel Sinizm } & a)1-5 yıl & 131 & 16,65 & 5,45 & \multirow{5}{*}{1,856} & \multirow{5}{*}{0,119} & \multirow{5}{*}{ - } \\
\hline & b)6-10 yil & 69 & 16,30 & 5,03 & & & \\
\hline & c) $11-15 \mathrm{yll}$ & 24 & 14,67 & 4,62 & & & \\
\hline & d) $16-20 \mathrm{yll}$ & 12 & 13,50 & 6,43 & & & \\
\hline & e) 21 yıl ve üstü & 4 & 13,00 & 6,88 & & & \\
\hline \multirow{5}{*}{$\begin{array}{l}\text { Duygusal } \\
\text { Sinizm }\end{array}$} & a)1-5 yıl & 131 & 11,71 & 4,79 & \multirow{5}{*}{1,366} & \multirow{5}{*}{0,246} & \multirow{5}{*}{ - } \\
\hline & b)6-10 yıl & 69 & 11,35 & 4,10 & & & \\
\hline & c) $11-15 \mathrm{yll}$ & 24 & 10,17 & 3,73 & & & \\
\hline & d)1-20 yil & 12 & 9,58 & 5,37 & & & \\
\hline & e) 21 yıl ve üstü & 4 & 8,75 & 7,09 & & & \\
\hline \multirow{5}{*}{$\begin{array}{l}\text { Davranışsal } \\
\text { Sinizm }\end{array}$} & a)1-5 yıl & 131 & 13,98 & 4,38 & \multirow{5}{*}{2,555} & \multirow{5}{*}{0,053} & \multirow{5}{*}{ - } \\
\hline & b)6-10 y1l & 69 & 14,04 & 3,09 & & & \\
\hline & c) $11-15 \mathrm{yll}$ & 24 & 12,38 & 3,92 & & & \\
\hline & d)16-20 yıl & 12 & 10,76 & 5,14 & & & \\
\hline & e) 21 yıl ve üstü & 4 & 13,00 & 3,56 & & & \\
\hline
\end{tabular}

$\mathrm{p}>0,05$

Katılımcıların mevcut işletmedeki çalışma yılı ile örgütsel sinizm ( $\mathrm{F}=2,111 ; \mathrm{p}>0,05)$, bilişsel sinizm alt boyutu $(\mathrm{F}=1,856 ; \mathrm{p}>0,05)$, duygusal sinizm alt boyutu $(\mathrm{F}=1,366 ; \mathrm{p}>0,05)$ ve davranışsal sinizm alt boyutu $(\mathrm{F}=2,555$; p>0,05) arasında anlamlı bir farklılık bulunmamıştır. H8, H8a, H8b, H8c hipotezleri reddedilmiştir.

Tablo 12. Gelir Değişkeni İçin ANOVA Testi Sonuçları

\begin{tabular}{|c|c|c|c|c|c|c|c|}
\hline & Gelir & $\mathbf{n}$ & Ort & SS & $\mathbf{F}$ & $p$ & Farklılık \\
\hline \multirow{5}{*}{ Toplam Puan } & a) $1500-2000 \mathrm{TL}$ & 13 & 49,54 & 11,07 & \multirow{5}{*}{5,929} & \multirow{5}{*}{$0,000^{*}$} & \multirow{5}{*}{$\begin{array}{l}a>e \\
b>e\end{array}$} \\
\hline & b)2001-3000 TL & 76 & 44,51 & 13,54 & & & \\
\hline & c)3001-4000 TL & 51 & 41,33 & 11,08 & & & \\
\hline & d)4001-5000 TL & 45 & 39,38 & 12,69 & & & \\
\hline & e) 5001 TL ve üstü & 55 & 35,53 & 12,00 & & & \\
\hline \multirow{5}{*}{ Bilişsel Sinizm } & a) $1500-2000 \mathrm{TL}$ & 13 & 18,46 & 4,86 & \multirow{5}{*}{6,483} & \multirow{5}{*}{$0,000^{*}$} & \multirow{5}{*}{$\begin{array}{l}a>e \\
b>e \\
c>e\end{array}$} \\
\hline & b) $2001-3000 \mathrm{TL}$ & 76 & 17,72 & 5,52 & & & \\
\hline & c) $3001-4000 \mathrm{TL}$ & 51 & 16,63 & 4,87 & & & \\
\hline & d)4001-5000 TL & 45 & 15,47 & 4,96 & & & \\
\hline & e) 5001 TL ve üstü & 55 & 13,47 & 5,04 & & & \\
\hline \multirow{5}{*}{$\begin{array}{l}\text { Duygusal } \\
\text { Sinizm }\end{array}$} & a) $1500-2000 \mathrm{TL}$ & 13 & 14,77 & 4,11 & \multirow{5}{*}{5,122} & \multirow{5}{*}{$0,001^{*}$} & \multirow{5}{*}{$\begin{array}{l}a>d \\
a>e \\
b>e\end{array}$} \\
\hline & b) $2001-3000 \mathrm{TL}$ & 76 & 12,22 & 4,60 & & & \\
\hline & c) $3001-4000 \mathrm{TL}$ & 51 & 11,33 & 3,91 & & & \\
\hline & d)4001-5000 TL & 45 & 10,84 & 4,55 & & & \\
\hline & e) 5001 TL ve üstü & 55 & 9,53 & 4,64 & & & \\
\hline \multirow{5}{*}{$\begin{array}{l}\text { Davranışsal } \\
\text { Sinizm }\end{array}$} & a) $1500-2000 \mathrm{TL}$ & 13 & 16,31 & 3,01 & \multirow{5}{*}{3,829} & \multirow{5}{*}{$0,005^{*}$} & \multirow{5}{*}{$\begin{array}{l}a>e \\
b>e\end{array}$} \\
\hline & b) $2001-3000 \mathrm{TL}$ & 76 & 14,57 & 4,53 & & & \\
\hline & c) $3001-4000 \mathrm{TL}$ & 51 & 13,37 & 3,39 & & & \\
\hline & d)4001-5000 TL & 45 & 13,07 & 4,24 & & & \\
\hline & e)5001 TL ve üstü & 55 & 12,53 & 3,69 & & & \\
\hline
\end{tabular}

${ }^{*} \mathrm{p}<0,01$ 
Katılımcıların gelirleri ile örgütsel sinizm $(F=5,929 ; p<0,01)$, bilişsel sinizm alt boyutu $(F=6,483 ; p<0,01)$, duygusal sinizm alt boyutu $(\mathrm{F}=5,122 ; \mathrm{p}<0,01)$ ve davranıssal sinizm alt boyutu $(\mathrm{F}=3,829 ; \mathrm{p}<0,01)$ toplam puanları arasında anlamlı farklılıkların bulunduğu tespit edilmiştir. H9, H9a, H9b, H9c hipotezleri kabul edilmiştir. Farkın hangi gruplar arasında olduğunu belirlemek için örgütsel sinizm ölçeği, bilişsel sinizm alt boyutu, duygusal sinizm alt boyutu ve davranışsal sinizm alt boyutu toplam puan varyanslarına bakılmış ve varyanslar homojen olmadığı için Games-Howell testi yapılmıştır. Geliri 1500-2000 TL ve 2001-3000 TL arasında olan çalışanların örgütsel sinizm toplam puanları geliri $5001 \mathrm{TL}$ ve üstü olanlardan anlamlı bir şekilde yüksek olduğu tespit edilmiştir. Geliri 1500-2000 TL, 2001-3000 TL ve 3001-4000 TL arasında olan çalışanların bilişsel sinizm toplam puanları geliri $5001 \mathrm{TL}$ ve üstü olanlardan anlamlı bir şekilde yüksek olduğu tespit edilmiştir. Geliri 1500-2000 TL arasında olan çalışanların duygusal sinizm toplam puanları geliri 4001 TL ve üstü olanlardan anlamlı bir şekilde daha yüksek olduğu ve geliri 2001-3000 TL arasında olan çalışanların da duygusal sinizm toplam puanları geliri $5001 \mathrm{TL}$ ve üstü olanlardan daha yüksek olduğu tespit edilmiştir. Ayrıca geliri 1500-2000 TL ve 2001-3000 TL arasında olan çalışanların davranışsal sinizm toplam puanları geliri 5001 TL ve üstü olan çalışanlara göre anlamlı bir şekilde daha yüksek olduğu görülmektedir.

Tablo 13. Günlük Çalışma Saati Değişkeni İçin T-Testi Sonuçları

\begin{tabular}{|c|c|c|c|c|c|c|}
\hline & $\begin{array}{l}\text { Günlük } \\
\text { Çalışma Saati }\end{array}$ & $\mathbf{n}$ & Ort & SS & $t$ & p \\
\hline \multirow[t]{2}{*}{ Toplam Puan } & 8 saat ve altı & 72 & 38,01 & 12,07 & \multirow[t]{2}{*}{$-2,438$} & \multirow[t]{2}{*}{$0,015^{*}$} \\
\hline & 9 saat ve üstü & 168 & 42,41 & 13,08 & & \\
\hline \multirow[t]{2}{*}{ Bilişsel Sinizm } & 8 saat ve altı & 72 & 14,67 & 4,95 & \multirow[t]{2}{*}{$-2,811$} & \multirow[t]{2}{*}{$0,005^{*}$} \\
\hline & 9 saat ve üstü & 168 & 16,76 & 5,43 & & \\
\hline \multirow{2}{*}{$\begin{array}{l}\text { Duygusal } \\
\text { Sinizm }\end{array}$} & 8 saat ve altı & 72 & 10,42 & 4,37 & \multirow[t]{2}{*}{$-1,955$} & \multirow[t]{2}{*}{0,052} \\
\hline & 9 saat ve üstü & 168 & 11,67 & 4,64 & & \\
\hline \multirow{2}{*}{$\begin{array}{l}\text { Davranışsal } \\
\text { Sinizm }\end{array}$} & 8 saat ve alt1 & 72 & 12,93 & 3,94 & \multirow[t]{2}{*}{$-1,815$} & \multirow[t]{2}{*}{0,071} \\
\hline & 9 saat ve üstü & 168 & 13,97 & 4,12 & & \\
\hline
\end{tabular}

$\mathrm{p}>0,05,{ }^{*} \mathrm{p}<0,05$

Katılımcıların günlük çalı̧̧ma saatleri ile örgütsel sinizm $(t=-2,438 ; p<0,05)$ ve bilişsel sinizm alt boyutu ( $t=-$ $2,811 ; \mathrm{p}<0,05)$ toplam puanları arasında anlamlı bir farklılı̆̆ın bulunduğu tespit edilmiştir. Duygusal sinizm alt boyutu $(t=-1,955 ; p>0,05)$ ve davranışsal sinizm alt boyutu $(t=-1,815 ; p>0,05)$ toplam puanları arasında ise farklılık tespit edilmemiştir. H10 ve H10a hipotezleri kabul edilirken, H10b ve H10c hipotezleri reddedilmiştir. Araştırma örneklem kapsamında, günlük 9 ve daha fazla saat çalışanların örgütsel ve bilişsel sinizm toplam puanlarının günlük 8 ve daha az çalışanlardan anlamlı bir şekilde yüksek olduğu tespit edilmiştir.

\section{SONUÇ VE TARTIŞMA}

Örgütsel sinizm örgütler açısından üzerinde durulması gereken önemli sorunlar arasında yer almaktadır. Örgütsel sinizme karşı örgütlerin gerekli tedbirleri almaları örgüt başarısı yönünden büyük önem taşımaktadır. Çünkü işletmelerde çalışanların örgütsel sinizm düzeylerinde artış yaşanması hem işletmenin gelecekteki durumunu hem de çalışanların performans seviyesini olumsuz etkilediği bilinmektedir (Abraham, 2000; Reichers vd., 1997; Akdemir vd., 2016; Bacaksiz vd., 2018).

İmalat sanayi çalışanlarının örgütsel sinizm düzeylerinin belirlenmesi ve çalışanların sosyo-demografik özelliklerinin örgütsel sinizm düzeylerinde anlamlı bir farklılığa neden olup olmadığının tespit edilmesi gibi amaçlarla yapılan bu çalışmada, katılımcıların genel örgütsel sinizm ortalamaları orta düzeydedir $(3,16)$. Bunula birlikte; bilişsel sinizm $(3,22)$, duygusal sinizm $(2,82)$ ve davranışsal sinizm $(3,46)$ ortalamaları da orta düzeydedir. Bu açıdan Tayfun ve Çatır (2014), Akyüz (2014), Çalbay (2016), Ağırdan (2016) tarafından yapılan ve orta düzeyde çalışan sinizmi bulunan çalışmalarla paralellik göstermektedir. Bu bulgulara göre, çalışanların davranışsal sinizm düzeyleri hem diğer boyutlara göre hem de örgütsel sinizmin geneline göre daha yüksektir. Dolayısıyla çalışanların daha çok negatif ve küçümseyici davranışta bulunma eğiliminde olduğu, örgütüne karşı sert eleştirilerde ve kötümser tahminlerde bulunduğunu söylemek mümkündür. 
Çalışanların; eğitim düzeyleri, statüleri, gelir seviyeleri ve günlük çalışma süreleri ile genel örgütsel sinizm düzeyleri ve boyutları arasında anlamlı farklılıklar tespit edilmiştir.

Eğitim düzeyi değişkeni yönünden değerlendirme yapıldığında; genel örgütsel sinizm ve üç alt boyutu arasında da anlamlı farklılıklar bulunmuştur. Buna göre, ilköğretim mezunu çalışanların örgütsel sinizm, bilişsel sinizm, duygusal sinizm ve davranışsal sinizm toplam puanlarının ön lisans ve lisans mezunu çalışanlardan anlamlı bir şekilde yüksek olduğu tespit edilmiştir. Ayrıca lise mezunu çalışanların örgütsel sinizm, bilişsel sizim ve davranışsal sinizm toplam puanlarının ön lisans ve lisans mezunu olanlara göre daha yüksek olduğu tespit edilmiştir. Genel olarak eğitim seviyesi arttıkça sinizm düzeyinin azaldığını söylemek mümkündür. Bu sonuç Altınöz vd. (2011) ve Pelit ve Ayana (2016) çalışmalarıyla benzerlik arz etmektedir. Fakat çalışanların artan eğitim seviyesinin örgütsel sinizmi de arttırdığı yönünde bulgular olan çalışmalar da mevcuttur (Fero, 2005; Güzeller ve Kalağan, 2008).

Statü değişkeni yönünden değerlendirme yapıldığında; genel örgütsel sinizm, bilişsel sinizm ve duygusal sinizm toplam puanları arasında anlamlı farklılıklar tespit edilmiştir. Bu sonuca göre, işçilerin genel örgütsel sinizm, bilişsel sinizm ve duygusal sinizm toplam puanlarının yöneticilere göre yüksek olduğu tespit edilmiştir. Dolayısıyla işçilerin yöneticilere göre daha fazla örgütsel sinizm yaşadığı yorumu yapılabilir. Bunun nedeninin işletmelerde halen devam ettirilen geleneksel ast-üst ilişkisinden kaynaklandığı düşünülmektedir. Elde edilen bu sonuç literatürde Öğüt vd. (2008) tarafından yapılan çalışmayla paralellik arz etmektedir.

Gelir değişkeni yönünden değerlendirme yapıldığında; genel örgütsel sinizm ve üç alt boyutu arasında da anlamlı farklılıklar bulunmuştur. Geliri 1500-2000 TL ve 2001-3000 TL arasında olan çalışanların örgütsel sinizm toplam puanları geliri $5001 \mathrm{TL}$ ve üstü olanlardan anlamlı bir şekilde yüksek olduğu tespit edilmiştir. Geliri 1500-2000 TL, 2001-3000 TL ve 3001-4000 TL arasında olan çalışanların bilişsel sinizm toplam puanları geliri 5001 TL ve üstü olanlardan anlamlı bir şekilde yüksek olduğu tespit edilmiştir. Geliri 1500-2000 TL arasında olan çalışanların duygusal sinizm toplam puanları geliri 4001 TL ve üstü olanlardan anlamlı bir şekilde daha yüksek olduğu ve geliri 2001-3000 TL arasında olan çalışanların da duygusal sinizm toplam puanları geliri 5001 TL ve üstü olanlardan daha yüksek olduğu tespit edilmiştir. Ayrıca geliri 1500-2000 TL ve 2001-3000 TL arasında olan çalışanların davranışsal sinizm toplam puanları geliri 5001 TL ve üstü olan çalışanlara göre anlamlı bir şekilde daha yüksek olduğu görülmektedir. Tam olarak gelir seviyesi düştükçe örgütsel sinizm düzeyi artar yorumunun yapılması doğru olmasa da genel olarak düşük gelir seviyesine sahip olan çalışanların sinizm toplam puanlarının gelir seviyesi yüksek olanlara göre yüksek olduğu tespit edilmiştir. Dolayısıyla gelir seviyesi örgütsel sinizm üzerinde etkilidir. Bu sonuç Mirvis ve Kanter (1991), Fero (2005) ve Kalağan (2009) çalışmalarıyla örtüşmektedir.

Günlük çalışma süresi değişkeni yönünden değerlendirme yapıldığında; genel örgütsel sinizm ve bilişsel sinizm toplam puanları arasında anlamlı farklılıklar tespit edilmiştir. Günlük 9 ve daha fazla saat çalışanların örgütsel ve bilişsel sinizm toplam puanlarının günlük 8 ve daha az çalışanlardan anlamlı bir şekilde yüksek olduğu tespit edilmiştir. Araştırmanın yapıldığı işletmelerde çalışanların 6 gün işe geldiği tespit edilmiş ve bu doğrultuda günlük yasal çalışma saatinin 7,5 saat (Koçak, 2020) olduğu dikkate alındığında bu yasal süreyi geçenlerin daha fazla genel örgütsel sinizm ve bilişsel sinizm davranışı sergilediği sonucuna ulaşılmıştır.

Diğer sosyo-demografik değişkenlere göre bir değerlendirme yapıldığında ise; çalışanların genel örgütsel sinizm ve boyutları arasında anlamlı farklılıklara rastlanmamıştır. Cinsiyet değişkeni ve medeni durum değişkeni ile örgütsel sinizm düzeyleri arasında anlamlı bir fark bulunmamıştır. Bu durum Kalağan ve Güzeller (2010), Mirvis ve Kanter (1991) ve Andersson ve Bateman (1997)'in çalışmalarıyla benzerlik taşımaktadır. Yaş değişkeni ile örgütsel sinizm düzeyleri arasında da anlamlı bir fark bulunmamıştır. Mirvis ve Kanter (1991) ve Andersson ve Bateman (1997) çalışmalarında yaş değişkeninin sinizm üzerinde etkili olduğunu bulmuşlardır. Bu sebeple bu araştırmada elde edilen sonuç diğerlerinden farklılık arz etmektedir.

$\mathrm{Bu}$ araştırmanın bulgularından yola çıkarak örgütsel sinizmi minimum seviyeye indirgemek hatta ortadan kaldırmak adına aşağıda belirtilen öneriler tavsiye edilmektedir:

- İşletme kapsamındaki politika, amaç ve uygulamalar uyumlaştırılmalıdır.

- İşletme içerisinde ödül ya da terfi benzeri uygulamalarda adalet sağlanmalıdır. 


\section{B. Erer - M. Şahin 12/3 (2020) 2944-2959}

- Örgütsel sinizmin engellenmesi ve sinizme olan farkındalığın arttırılması için işletmelerde gerekli eğitimlerin verilmesi gerekmektedir.

- Örgütsel sinizme engel olmak adına örgüt içinde etkin bir iletişim yapısının kurulması sağlanmalıdır.

- İşletmelerdeki ast-üst ilişkilerinin geleneksel yöntemlerden ziyade çağdaş yöntemler dikkate alınarak sürdürülmesi örgütsel sinizm davranışlarını azaltma adına yararlı olabilir.

- Çalışanların en azından çalışma saatleri dikkate alınarak gelir seviyelerinde iyileştirmelere gidilmelidir.

- İşletme içindeki çalışma şartları ve saatleri değiştirilmeli ve mümkün olduğunca yasal çalışma saatleri dikkate alınmalıdır.

Yoğun rekabet sebebiyle işletmelerin yaşamlarını sürdürebilmesi için emek yoğun işletmelerin diğer işletmelere göre daha fazla çaba harcamaları gereklidir (Şahin ve Ateş 2017: 22). Bu doğrultuda işletmelerin bulundukları sektör örgütsel sinizm üzerinde de etki sahibi olabilecektir. Örgütsel sinizm ile ilgili gelecekte yapılması öngörülen çalışmalar için; çalışma alanı genişletilerek aynı sektörde ya da farklı sektörlerde yapılması ayrıca araştırmanın sınırlılığı olarak Konya ili ile kısıtlı olması diğer illerle kıyaslama yapılmasına imkân vermediğinden uygulamanın farklı illerde gerçekleştirilmesi bilimsel alan yazına katkı sağlayabilecektir.

\section{KAYNAKÇA}

Abraham, F. R. (2000). Organizational Cynicism: Bases and Consequences, Genetic, Social, and General Psychology Monographs, 126 (3), 269-292.

Ağırdan, Ö. (2016). Örgütsel Sinizm: Hastane Çalışanları Üzerine Bir Araştırma. Yüksek Lisans Tezi, İstanbul Kültür Üniversitesi Sosyal Bilimler Enstitüsü, İstanbul.

Akdemir, B., Kırmızıgül, B. ve Zengin, Y. (2016). Örgütsel Sinizm İle İş Performansı Arasındaki İlişki ve Bir Araştırma, Kahramanmaraş Sütçü İmam Üniversitesi İktisadi ve İdari Bilimler Dergisi, 6(2), 115-130.

Akgemci, T., Kareem, A. A. ve Kızıloğlu, E. (2020). Örgüt İkliminin Örgüt Temelli Özsaygı ve Öznel İyi Oluş Üzerindeki Etkisi: Kobi'ler Üzerinde Bir Araştırma, Journal Of Busıness Research-Turk, 12(1), 65-78.

Akyüz, İ., ve Yurduseven, N. O. (2016). Sağlık Çalışanlarının Örgütsel Sinizm Düzeylerinin İncelenmesi. International Journal of Economic \& Administrative Studies,16, 61-75.

Altınöz, M., Çöp, S., ve Sığındı, T. (2011). Algılanan örgütsel bağl1lık ve örgütsel sinizm ilişkisi: Ankara'daki dört ve beş yıldızlı konaklama işletmeleri üzerine bir araştırma. Selçuk Üniversitesi İktisadi İdari Bilimler Fakültesi Sosyal ve Ekonomik Araştırmalar Dergisi, 11 (21), 285-315.

Andersson, L. and Bateman, T. (1997). Cynicism in The Workplace: Somecauses and Effects, Journal of Organizational Behavior, 18 (5), 449- 469.

Bacaksız, F. E., Tuna, R. and Seren, A. K. (2018). Sağlık Çalışanlarında Performans ve Örgütsel Sinizm İlişkisi: Hemşireler Üzerinde Bir Araştırma, ACU Sağ lık Bilimleri Dergisi, 9(1), 52-58.

Brandes, P. (1997). Organizational Cynicism: Its Nature, Antecedents and Consequences, University of Cincinnati, Doctoral Thesis, 34-35.

Brandes, P., Dharwadkar, R. and Dean, J. W. (1999). Does Organizational Cynicism Matter? Employee And Supervisor Perspectives On Work Outcomes, The 36th Annual Meeting of the Eastern Academy of Management Proceedings, Philadelphia.

Cartwright S. and Holmes N. (2006) The Meaning of Work: The Challenge of Regaining Employee Engagement and Reducing Cynicism. Human Resource Management Review 16(2): 199-208.

Çalbay, S. (2016). Hemşirelerde Örgütsel Sinizm Düzeylerinin Belirlenmesi. Yüksek Lisans Tezi, İstanbul Medipol Üniversitesi Sağlık Bilimleri Enstitüsü, İstanbul.

Çankaya, M. (2018). Hastane Çalışanlarının Örgütsel Sinizm Düzeylerinin İncelenmesi, MANAS Sosyal Araştırmalar Dergisi, 7(4), 287-306. 


\section{B. Erer - M. Şahin 12/3 (2020) 2944-2959}

Çankaya, M. (2020). Sağlık Çalışanlarında Toksik Liderlik Algısı, Çobanoğlu Y. (Ed.) Sosyal, Beşeri ve İdari Bilimler Alanında Akademik Çalışmalar Cilt 3, Gece Kitaplığı Yayınevi, Ankara, 265-281.

Dean, W. J., Brandes, P. and Dharwadkar R. (1998). Organizational Cynicism, The Academy of Management Review, 23, 345-346.

Efilti, S., Gönen, Y. and Öztürk, F. (2008). Örgütsel Sinizm: Akdeniz Üniversitesi'nde Görev Yapan Yönetici Sekreterler Üzerinde Bir Alan Araştırması, 7. Ulusal Büro Yönetimi ve Sekreterlik Kongresi, Trabzon: Karadeniz Teknik Üniversitesi, 1-14.

Fero, H. C. (2005). Flow and Cynicism in the Workplace. Dissertation of Doctor of Philosophy, Claremont Graduate University, Claremont, California.

Gençer, Ö. E. (2017). Örgütsel Adalet Algısının Sinizm Üzerine Etkisi: Devlet Üniversiteleri Meslek Yüksekokullarında Bir Araştırma, Yüksek Lisans Tezi, Gazi Üniversitesi Sosyal Bilimler Enstitüsü, Ankara.

Güzeller, C., ve Kalağan, G. (2008). Örgütsel sinizm ölçeğinin Türkçe'ye uyarlanması ve çeşitli değişkenler açısından eğitim örgütlerinde incelenmesi, 16. Ulusal Yönetim ve Organizasyon Kongresi Bildiri Kitabı, 87-94.

James, M. S. L. (2005). Antecedents and Consequences of Cynicism in Organizations: An Examination of the Potential Positive and Negative Effects on School Systems, Unpublished Doctoral Dissertation, The Florida State University, USA.

Kalağan, G. (2009). Araştırma Görevlilerinin Örgütsel Destek Algıları ile Örgütsel Sinizm Tutumları Arasındaki Ilişki. Yayınlanmamış Yüksek Lisans Tezi, Akdeniz Üniversitesi, Sosyal Bilimler Enstitüsü, Antalya.

Kalağan, G. ve Güzeller, C. O. (2010). Öğretmenlerin Örgütsel Sinizm Düzeylerinin İncelenmesi, Pamukkale Üniversitesi Ĕ̆itim Fakültesi Dergisi, 27, 83-97.

Kalay, F., Oğrak, A. ve Nişancı Z. N. (2014), Mobbing, Örgütsel Sessizlik ve Örgütsel Sinizm İlişkisi: Örnek Bir Uygulama, Kastamonu University Journal Of Economics \& Administrative Sciences Faculty, 4(2), 127-143.

Karacaoğlu, K. ve İnce, F. (2012). Brandes, Dharwadkar ve Dean'in (1999) Örgütsel Sinizm Ölçeği Türkçe Formunun Geçerlilik ve Güvenilirlik Çalışması: Kayseri Organize Sanayi Bölgesi Örneği, Business and Economics Research Journal, 3(3), 77-92.

Karadeniz, M. E. (2017). Üstünlük Vehmi Ve Örgütsel Sinizm İlişkisi: Akademisyenler Üzerinde Bir Çalışma, Yüksek Lisans Tezi, Süleyman Demirel Üniversitesi Sosyal Bilimler Enstitüsü, Isparta.

Koçak, O. (2020). İşçilerin Günlük ve Haftalık Çalışma Saati, https://www.calismamevzuati.com/2020/02/ iscilerin-gunluk-ve-haftalik-calisma-saati/ (Erişim Tarihi: 23.06.2020).

Kutanis, R. E. ve Çetinel, E. (2010). Adalet Algısı Sinizmi Tetikler Mi?: Bir Örnek Olay, Dumlupınar Üniversitesi Sosyal Bilimler Dergisi, 1(26),186-195.

Mantere, S. and Martinsuo, M. (2001). Adopting and questioning strategy: exploring the roles of cynicism and dissent.. European Group for Organisation Studies, 17th EGOS Colloquium, July 5-7, 2001 Lyon, France.

Mirvis, P. H. and Kanter, D. L. (1991). Beyond Demography: A Psychographic Profile of The Workforce. Human Resource Management, 30(1), 45-68.

Mishna, A. K. and Spreitzer, G. M. (1998). Explaining How Survivors Respond to Downsizing: The Roles of Trust, Empowerment, Justice, and Work Redesign, The Academy of Management Review, 23(3), 567- 588.

Öğüt, A., Özgener, Ş. ve Kaplan, M. (2008). The Interaction Between Organizational Cynicism and Psychological Contract Violation in Terms of Strategic Human Resource Management. 4. International Strategic Management Conference,19-21 June 2008, Sarajevo, Bosnia Herzegovina.

Özgener, Ş., Öğüt A. ve Kaplan, M. (2008). İşgören- İşveren İlişkilerinde Yeni Bir Paradigma: Örgütsel Sinizm. Özdevecioğlu M.ve Karadal H.( ed.), Örgütsel Davranışta Seçme Konular, Organizasyonların Karanlık Yönleri ve Verimlilik Azaltıcı Davranışlar. Ankara: İlke Yayınevi, 53-72. 
B. Erer - M. Şahin 12/3 (2020) 2944-2959

Pelit, E., ve Ayana, Ç. (2016). Duygusal zekanın örgütsel sinizme etkisi: Otel işletmeleri işgörenleri üzerine yapılmış bir araştırma. Journal of Business Research Turk, 8(2), 45-76.

Pelit, N. ve Pelit E. (2014). Örgütlerde Kanser Yapıcı İki Başat Faktör: Mobbing ve Örgütsel Sinizm, 1.Baskı, Ankara: Detay Yayıncilık

Reichers, A. E., Wanous, J. P. and Austin, J. T. (1997). Understanding and Managing Cynicism about Organizational Change, The Academy of Management Executive, 11(1), 48-59.

Rubin, R. S., Dierdorff, E. C., Bommer, W. H. and Baldwin, T. T. (2009). Do Leaders Reap What They Sow? Leader And Employee Outcomes Of Leader Organizational Cynicism About Change, The Leadership Quarterly, 20, 680-688.

Şahin, M. Ve Ateş A. (2017). İş Hayatında Tükenmişlik Ve Seyahat Acentası Çalışanlarının Tükenmişlik Düzeylerini Belirlemeye Yönelik Bir Araştırma. Uluslararası Hakemli İletişim Ve Edebiyat Araştırmaları Dergisi, 16, 21-39.

Tayfun, A., ve Çatır, O. (2014). Hemşirelerin örgütsel sinizm düzeylerinin incelenmesi. İşletme Araştırmaları Dergisi, 6(1), 347-365.

Tınaztepe, C. (2012). Örgüt İçi Etkin İletişimin Örgütsel Sinizme Etkisi, Organizasyon ve Yönetim Bilimleri Dergisi, 53-63.

Tokgöz, N. ve Yılmaz, H. (2008). Örgütsel Sinizm: Eskişehir ve Alanya'daki Otel İşletmelerinde Bir Uygulama, Anadolu Üniversitesi Sosyal Bilimler Dergisi, 8(2), 238-305.

Yalçın, İ., ve Koyuncu, S. C. (2014). Örgütsel Yabancılaşma Olgusunun İş Tatmini Üzerine Etkisi: Niğde İlinde Bir Araştırma, Karamanoğlu Mehmet Bey Üniversitesi Sosyal ve Ekonomik Araştırmalar Dergisi, 16(26), 86-94.

Yılmaz, F., İşeri, İ. ve Çolak, Y. M. (2016). Ankara'da Özel Hastanede Çalışanların Sinizm ve Örgütsel Sinizm Düzeyleri, Akademik Bakış Dergisi, 429-444. 